Materiales de Construcción

Vol. 70, Issue 338, April-June 2020, e219

ISSN-L: 0465-2746

https://doi.org/10.3989/mc.2020.08619

\title{
Adapted ageing tests for the evaluation of alabaster used in the restoration of Bishop's Palace of Tarazona
}

\author{
R. Bustamante ${ }^{\mathrm{a}} \bowtie$, P. Vázquez ${ }^{\mathrm{b}}, \mathrm{P}$. Rodríguez-Monteverde ${ }^{\mathrm{a}}$, J. Monjo ${ }^{\mathrm{a}}$ \\ a. Universidad Politécnica de Madrid, Escuela Técnica Superior de Arquitectura, (Madrid, Spain) \\ b. GEGENAA EA3795, Université de Reims Champagne-Ardenne, (Reims, France) \\ $\triangle$ rosa.bustamante@upm.es
}

Received 10 June 2019

Accepted 19 December 2019

Available on line 26 March 2020

\begin{abstract}
The advanced condition of deterioration of the column's bases of the courtyard of the Bishop's Palace of Tarazona (Spain) built in the middle of 16th century required its restoration with Aragonese alabaster. Thus, adapted ageing tests were developed to simulate the environmental conditions in which the stones were and will be exposed. These tests were thermal fatigue by temperature variations, acid rain and water stagnation by immersion tests and a combination of both agents of decay. The results indicated that alabaster did not experimented deformation after thermal fatigue but a progressive dehydration to bassanite. This process entailed an increase of porosity and consequently a loss of structural properties. The dissolution was measured as a lineal weight and volume loss while porosity and capillary uptake remained stable. The conclusions of this study establish the importance of restoration protocols to maintain the alabaster integrity when used and exposed to rainwater and insolation.
\end{abstract}

KEYWORDS: Gypsum; Decay; Weathering; Petrography; Physical properties.

Citation/Citar como: Bustamante, R.; Vázquez, P.; Rodríguez-Monteverde, P.; Monjo, J. (2020) Adapted ageing tests for the evaluation of alabaster used in the restoration of Bishop's Palace of Tarazona. Mater. Construcc. 70 [338], e219 https://doi.org/10.3989/mc.2020.08619

RESUMEN: Ensayos de envejecimiento adaptados a la evaluación del alabastro de la restauración del Palacio Episcopal de Tarazona. Las basas deterioradas de las columnas del patio del Palacio Episcopal de Tarazona (España), construido a mediados del siglo XVI, fueron restauradas con alabastro aragonés. Por lo tanto, se han desarrollado pruebas de envejecimiento adaptadas para simular las condiciones ambientales en las que las piedras estaban y estarán expuestas, fatiga térmica por variaciones de temperatura, lluvia ácida, inmersión en agua y una combinación de agentes de deterioro. Los resultados indican que el alabastro no experimentó deformación después de la fatiga térmica, sino una progresiva deshidratación a bassanita, lo cual implica un aumento de porosidad y una pérdida de propiedades estructurales. La disolución se midió como una pérdida lineal de peso y volumen, mientras que la porosidad y el ascenso capilar se mantuvieron estables. Se desprende la importancia de adoptar protocolos de restauración para mantener la integridad del alabastro cuando se expone al agua de lluvia e insolación.

PALABRAS CLAVE: Yeso; Deterioro; Erosión; Petrografía; Propiedades físicas.

ORCID ID: R. Bustamante (https://orcid.org/0000-0003-0615-9410); P. Vázquez (https://orcid.org/0000-0002-5392-6451); P. Rodríguez-Monteverde (https://orcid.org/0000-0002-1477-7836); J. Monjo (https://orcid.org/0000-0003-2191-834X)

Copyright: (C) 2020 CSIC. This is an open-access article distributed under the terms of the Creative Commons Attribution 4.0 International (CC BY 4.0) License. 


\section{INTRODUCTION}

Alabaster is a stone that has been used since centuries in buildings, mainly for decorative purposes, altarpieces and window enclosures (1). Sometimes, it exhibited clays filling fissures, simulating marble features. This particularity, together with the easiness to sculpt it, made the alabaster a stone commonly used for sculpture and ornaments. Alabaster is a very low porosity stone with anisotropic thermal expansion $\left(\mathrm{a}, \mathrm{b}\right.$ and $\mathrm{c}$ are $3.98 \times 10^{-6}, 4.36 \times 10^{-5}$ and $2.53 \times 10^{-5} \mathrm{~K}^{-1}$, respectively) (2). This mineral anisotropy is the responsible to stone deformation forming surface grooves (3) and sometimes bowing (4). This phenomenon is commonly found in calcitic crystalline stones like marbles (5), although in other polycrystalline stones as granites was also recognized (6). This particularity, added to its high dissolution potential, makes alabaster extremely susceptible to decay, and consequently it is used mainly in sculptures and other indoors ornaments. Nevertheless, they are not exempted to be found in outdoors constructions, being completely exposed to a fast and irreversible decay.

The isotopic analysis (sulfur, oxygen, strontium) in medieval and Renaissance artworks allowed to determine that the Nottingham quarries supplied Sweden, Iceland and Spain, and the Catalonian quarries (Spain) provided the material for the South of France (7). Aragon is a Spanish region well known for the "Aragonese alabaster" used in this country as wall ashlars, columns, enclosures of voids, pavements tiles and sculptural objects. Currently, it is employed in constructive elements such as interior partitions, exterior cladding panels and floor tiles, where translucency is not the only objective of the choice of material but also its aspect.

The main goal of this study is to evidence the alabaster decay agents when exposed indoors but mainly outdoors. This study is focused in the alabaster found in the court columns of Bishop's Palace of Tarazona (Aragon region, Spain), due to the permanent exposure of the columns bases to rainwater that caused loss of mass and alteration of the original shape. Although the restoration of these columns was already carried out, no reports about the weathering agents were done before it. Thus, this study will allow to assure if the interventions were adapted to the deterioration agent and they really will contribute to the long-term alabaster preservation.

\subsection{Restoration of court's columns}

The court columns were carved by the French stonemason Guillaume Brimbeuf during the pontificate of the bishop Juan González de Munébrega between 1556 and 1558, under the direction of the Piacenza artist Pietro Morone (8). The court is composed by two bodies, with four Tuscan columns, each one consisting of five pieces: base, bottom shaft, decorative ring with vegetal motifs, upper shaft with the heraldic shield of the bishop and capital. The original bases were deteriorated by capillary moisture and infiltration over centuries, due to rainwater had entered the court. This would have motivated a reinforcement of bases and bottom shafts with Portland cement mortar in the 60 s of the $20^{\text {th }}$ century (Figures 1.a and 1.b).

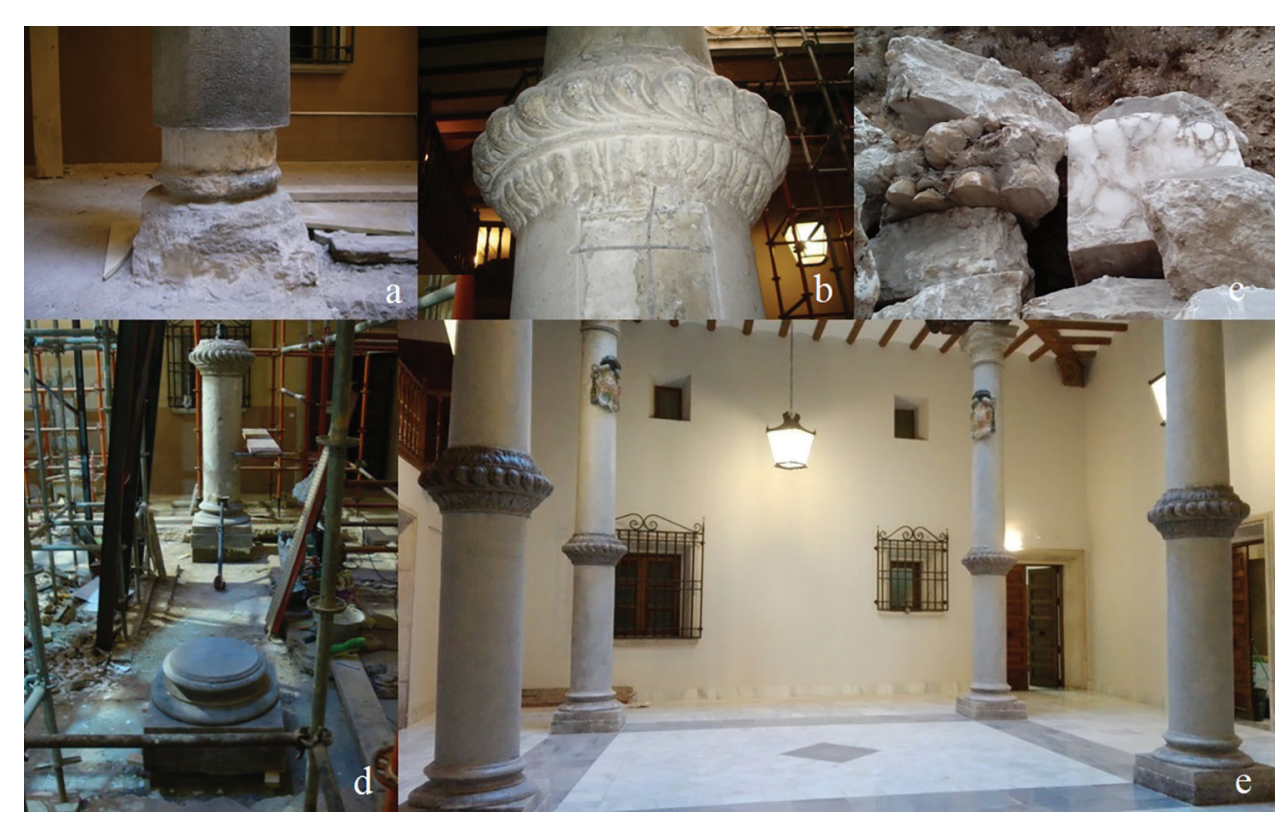

FigURE 1. a. Removal of mortar on base. b. Removal of reinforcement mortar that covered lower part of carved ring and shaft. c. Alabaster quarry. d. New bases. e. Restored alabastrine gypsum columns. 
In the restoration works carried out between 2016 and 2017 (9), the columns were dismantled to make a new concrete foundation. Previously the ground was consolidated with anchors and some floors of the palace were tied with stainless steel bars. Therefore, the reinforcing mortar of the bases was removed and new bases of alabaster of chromatic tonality similar to the previous ones were carved. The "bardillo" variety of Fuentes de Jiloca was chosen for this study since this is the alabaster that is currently being exploited (Figure 1.c). Then, the columns were reassembled (Figure 1.d). Knowing the vulnerability of the material to rainwater, the court has been covered with a glass skylight. In addition, a superficial cleaning was carried out, as well as the restitution of stucco of the bottom shaft and the polychrome of heraldic shields (Figure 1.e).

\section{METHODOLOGY}

\subsection{Material characterization}

Three parts of the column NE of the court were sampled in order to characterize the different alabaster features. The samples were obtained from the basis, the lower shaft and the upper shaft. XRD analysis was carried out with a Bruker D8 Advance equipment and the results analyzed with the DIFFRACplus software. Density and open porosity were obtained following the standard EN 1936 and water absorption by immersion following the standard EN 13755. Two samples, one from the column bases and other from the upper shaft were selected for a petrographic study with the polarized optical microscope Olympus AX-70. The water used for the hydric test was not distillated water as mentioned on the standard due to the low $\mathrm{pH}$ and the high solubility of alabaster stone. Water was enriched in $\mathrm{Ca}$ with a measured $\mathrm{pH}=7$ to avoid dissolution.

From fresh quarried stones, water absorption and density were determined following the mentioned standards. In addition, capillary water uptake, p-wave velocities and elasticity modulus, and uniaxial compression strength were obtained following the standards EN 1925, EN 14579, EN 14146 and EN 1926 respectively. The water used for the hydric tests was not distillated water as mentioned on the standard due to the low $\mathrm{pH}$ and the high solubility of alabaster stone. Water was enriched in $\mathrm{Ca}$ with a measured $\mathrm{pH}=7.2$ to avoid dissolution. In addition, the drying stage was carried out at $40^{\circ} \mathrm{C}$ until weight stabilization. The dynamic parameters were measured with a Pundit Plus avec transductors with a frequency of $54 \mathrm{MHz}$. Although alabaster did not show preferential orientation or bedding, $p$-waves were measured in three directions.

\subsection{Ageing tests}

Three different ageing tests were undertaken in order to simulate the weathering agents that may attack the alabaster bases and columns.

\section{Test 1: UV and Thermal fatigue}

This test was conceived to assess the effect of temperature changes on the alabaster stone. These variations can be of different nature, and due to that, the samples and the tests were adapted to obtain the maximum information. The first aim was to assess the deformation suffered by slabs (bowing) exposed to UV at high temperature conditions. For these purposes the selected samples were 6 slabs of dimensions $7 \mathrm{~cm} \times 3.5 \mathrm{~cm} \times 0.5 \mathrm{~cm}($ named $\mathrm{G})$ and 6 slabs of $7 \mathrm{~cm} \times 2.5 \mathrm{~cm} \times 0.5 \mathrm{~cm}($ named P). These two different widths were used to evaluate the influence of the slab dimension in the deformation.

The second aim was to determinate the color changes. Color was measured on the bigger slabs $(\mathrm{G})$ with a Minolta colorimeter CR-400 using the D65 illuminant, beam of diffuse light of $8-\mathrm{mm}$ diameter, $0^{\circ}$ viewing angle geometry, specular component included and spectral response closely matching the CIE standard observer curves. Measurements are expressed following the CIE $\mathrm{L}^{*} \mathrm{a}^{*} \mathrm{~b}^{*}$ systems. $\Delta \mathrm{E}^{*}$ is introduced as the total color change, to compare the variations before and after the tests as follows: $\Delta \mathrm{E}^{*}=\left[\left(\Delta \mathrm{L}^{*}\right) 2+\left(\Delta \mathrm{a}^{*}\right) 2+\left(\Delta \mathrm{b}^{*}\right) 2\right] 1 / 2$. A threshold of $\Delta \mathrm{E}=3$ is generally considered as the limit above which homogeneous color change is visible to the naked eye (10). Color variations were measured before the test, at the middle and at the end of the test in dry and dampened conditions.

The third aim was to study the microfissures evolution due to thermal fatigue. For this test, eight cubes of $3.5 \mathrm{~cm}$ edge were used.

Two consecutive tests were carried out, the UV exposure and the thermal fatigue. In the first test, all the samples were introduced at climatic chamber Suntest XXL + for sunshine ageing test in which three cycles were undertaken by day. Each cycle consisted in four hours of heating at $60^{\circ} \mathrm{C}$ plus UV radiation that involved a total temperature around $90^{\circ} \mathrm{C}-105^{\circ} \mathrm{C}$ followed of four hours of cooling at $20^{\circ} \mathrm{C}$ and in the darkness. The duration of this test was 20 cycles and the energy irradiated during this time was $1800 \mathrm{kWh} / \mathrm{m} 2$, equivalent to five years of real exposition in north of Spain. Capillary uptake, color, and deformation in the respective samples were measured after 10 cycles and at the end of this test.

After that, all the samples were exposed to the second test. They were introduced in a Votsch climatic chamber and submitted to 70 cycles of thermal fatigue, with one cycle consisting in four hours at $90^{\circ} \mathrm{C}$ followed by four hours at $20^{\circ} \mathrm{C}$ and the 
same parameters were measured at the end of this test. The heating and cooling rate were less than $2{ }^{\circ} \mathrm{C} / \mathrm{min}$, to avoid fracturation due to a sudden temperature change. Capillary water uptake, color and deformation were measured again after the tests. XRD analyses were carried out to determine if new mineral phases such as bassanite or anhydrite appeared. In addition, mercury injection porosimetry was measured with a Micromeritics Autopore IV 9500 to observe if porous network distribution varied with heating.

\section{Test 2: Acid Rain}

Two acid rain tests were carried out following the methodology developed in Eyssautier et al. (11). In both tests the aim was to calculate the surface recession and to observe physical changes in the alabaster. For each test, eight cubes of $3.5 \mathrm{~cm}$ edge were used. Weight $(\mathrm{g})$ and dimensions $(\mathrm{mm})$ were measured with 0.01 precision before the tests and after 1, 2, 3, and 4 weeks of ageing. In both tests the samples were immersed in a solution with a $\mathrm{pH}=5.6$ to simulate natural rain for 384 hours $(96 \mathrm{~h} \times 4$ weeks). This $\mathrm{pH}$ was obtained mixing tap water $(\mathrm{pH} \approx 7)$ with distillated water $(\mathrm{pH}=4.5)$ and renewed every $24 \mathrm{~h}$ to avoid a $\mathrm{pH}>6$. No acids were used in this test due to the nature of the stone and the possibility to create salt precipitations. Each week the cubes were dried in an oven at $60^{\circ} \mathrm{C}$ for 72 hours and then the weight and dimensions were measured again.

The first test carried out was named passive immersion (PI). It reproduced the effect of stagnated water at the basis of the column by the simple immersion of the cubes in the water solution. The second test was named active immersion (AI). It simulated the drivingrain and summer storms by the immersion of the samples in the water mixture and by placing the recipient in a shaking table with a movement frequency of $180 \mathrm{rpm}$. The concentrations of $\mathrm{Ca}^{2+}$ were measured from the solutions every day by Inductively Coupled Plasma - Atomic Emission Spectrometry (ICP-AES, Iris Advantage, Thermo Fisher Scientific). The analysis of $\mathrm{Ca} 2+$ was conducted at wavelength of 184.006 through three measurements of each solution. A $50 \mathrm{ml}$ aliquot of all the immersion solutions was sampled and stored at $4^{\circ} \mathrm{C}$ until chemical analyses.

\section{Test 3: Combined test}

A third test was developed to simulate real damage in the Tarazona palace columns. The test consisted in placing a prism of $7 \mathrm{~cm}$ height and $4.5 \mathrm{~cm}$ base in a film of distilled water. The film rises only $1 \mathrm{~mm}$ simulating capillary test. A cooling plate Tetech $\mathrm{CP} 061$ set at $60^{\circ} \mathrm{C}$ was placed in contact to one $7 \mathrm{~cm} \times 4.5 \mathrm{~cm}$ side. These two setups simulated the heating of the column during the day and stagnated water after rain. Cycles were performed with 6 hours of drying at $40^{\circ} \mathrm{C}$ in an oven followed by 18 hours of test. Due to the low capillarity of fresh stones, 6 hours at the selected temperature were enough to dry the surface humidity and cool down the sample. After four cycles of heating and cooling, the samples were dried in an oven at $40^{\circ} \mathrm{C}$ for 72 hours. Then the weight and dimensions as well as visual observation were measured. After the whole test, capillary water uptake was determined.

\section{RESULTS}

\subsection{Characterization of the weathered samples}

The petrographic characterization of the column samples (base and upper shaft) revealed that visually both samples showed a granular texture, with gypsum crystals of variable size $(0.1 \mathrm{~mm}$ to few $\mathrm{mm})$ as white and translucid crystals, both encompassed by a clayey brownish matrix. By microscopic assessment, three crystal distributions were observed in the base sample. The first type were gypsum aggregates of $1-2.5 \mathrm{~mm}$ with a crystal sizes of 20 to 100 $\mu \mathrm{m}$ with the typical alabastrine texture; the second one were allotriomorphic crystals with sizes comprised between $50 \mu \mathrm{m}$ and $0.5 \mathrm{~mm}$; the last type were subidiomorphic crystals of higher size, from 0.5 to $1.5 \mathrm{~mm}$ with anhydrite inclusions. This base sample showed $34 \%$ of alabastrine texture, $56 \%$ of granular subidiomorphic texture, $8 \%$ of marly matrix (clay and carbonate) and $2 \%$ or relict anhydrite. In the upper shaft, $75 \%$ of the sample revealed a granular subidiomorphic texture with crystals of very variable size, from 100 to $300 \mu \mathrm{m}$ generally, but up to $2500 \mu \mathrm{m}$ in rare cases. The alabastrine original texture was only represented in a $13 \%$, with gypsum crystals under $50 \mu \mathrm{m}$. In this sample, the marly matrix proportion with clays and carbonate was of $11 \%$ while relict anhydrite was only $1 \%$ (Figure 2 ).

Both samples from the base and the upper shaft came from the same rock block as deduced from its similar texture. The alabastrine texture can be considered as the original of the stone although the proportion of granular idiomorphic texture is more difficult to predict, it could belong to the original texture or the recrystallized one. In any case, the stone was a low quality alabaster due to the $10 \%$ of clays and carbonate matrix and commonly found and used in larger pieces than pure alabaster (12).

XRD analysis confirmed that the three samples obtained from the column (two from theshafts and one from the northeast base) were gypsum in its majority, with almost pure composition in the upper shaft $(93,4 \%)$ and a more clay-rich and partially transformed to bassanite in the base (gypsum $74 \%$, bassanite $3 \%$, phyllosilicates $14 \%$, quartz $4 \%$ and calcite $5 \%$ ). The porosity obtained by water 
absorption (EN 1936) revealed that the upper and bottom shaft showed values of around $14 \%$ and $6.5 \%$ respectively. The base sample had the lower porosity (around $2.5 \%$ ) explained by the phyllosilicates and clays filling the fissures.

The main petrophysical properties of the material are presented in Table 1 . The alabaster density was similar to that of other studies, capillary absorption was negligible, and the ultrasonic velocity was isotropic related to $\mathrm{X}, \mathrm{Y}$ and $\mathrm{Z}$ directions. Considering the compressive strength of the "bardillo" variety ("La Soledad" quarry, 4114'19.6”N 132'51.9"W) of $26.6 \mathrm{MPa}$ and the loads that each of the columns support $(0.45-0.69 \mathrm{MPa})$, a theoretical safety factor of 40 can be assumed. Although the columns were divided into 5 pieces, the resistance to compression must be considered more reduced by the effect of

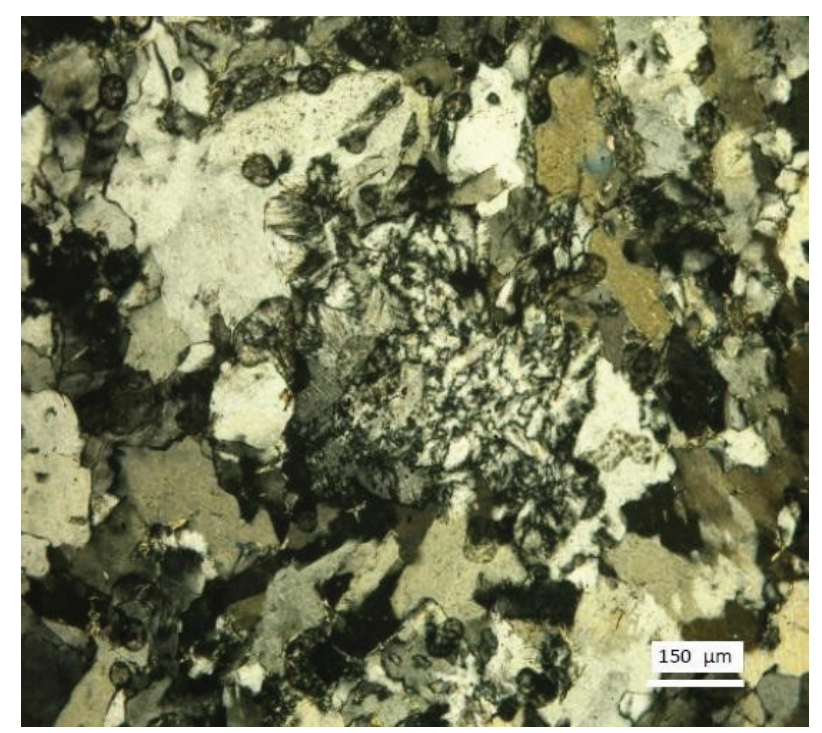

Figure 2. Alabastrine texture in the centre of upper shaft (12). eccentricity, and the differential movement of those pieces. Actually, the safety coefficient is around of 25 (eccentricity of $0.1 \mathrm{~m}$, and $1.4 \mathrm{MPa}$, maximum compression strength at the edge of the column). However, the eccentricity of the columns before the intervention was much greater and the safety coefficient reached values close to 5 to 4-5 MPa, maximum compression strength at the edge of the column.

\subsection{Characterization of the fresh samples}

Under microscope, the studied samples showed a granular texture with gypsum crystals of variable size from $70-350 \mu \mathrm{m}$ approximately and a proportion of around $70-75 \% \%$, and some aggregates with alabastrine texture and a proportion around $25 \%$. Also relict anhydrite with size around $80 \mu \mathrm{m}$ and a proportion of $1 \%$ was observed. DRX analyses of the sound sample revealed a composition of pure gypsum.

The physical properties calculated by hydric methods did not give valuable results. The extremely low porosity and fragility after water immersion of the alabaster induced a low error during manipulation, nevertheless enough to consider the results not reliable. Thus, mercury intrusion was used with coherent results as an open porosity of $0.67-0.72 \%$ and an apparent density of $2.3 \mathrm{~g} / \mathrm{cm}^{3}$. The pore distribution revealed a high open porosity over $10 \mu \mathrm{m}$ and few pore access radii of lesser size with some samples showing voids up to $0.005 \mu \mathrm{m}$.

\subsection{Ageing tests}

\subsubsection{Thermal fatigue}

After only ten cycles of UV exposure, the color variation due to the dehydration of gypsum to bassanite was flagrant. The samples showed a white powdery layer that spread out between 10 and

TABLE 1. Aragonese alabaster properties. Bulk density (D), Porosity accessible to water (P), Water absorption by immersion (WAbs), Capillary suction (C), Dynamic elastic modulus (Edyn); P-waves velocity (Vp); Flexural strength $(\sigma f)$, Compressive strength $(\sigma c)$.

\begin{tabular}{|c|c|c|c|c|c|c|c|c|c|}
\hline Source & Alabaster type & $\mathrm{D}\left(\mathrm{g} / \mathrm{cm}^{3}\right)$ & $\mathbf{P}(\%)$ & $\begin{array}{c}\text { WAbs } \\
24 \text { h }(\%)\end{array}$ & $\mathrm{C} \mathrm{g} / \mathrm{cm}^{2} \cdot \mathrm{min}^{0,5}$ & $\mathbf{E}_{\mathrm{dyn}}(\mathrm{GPa})$ & $\mathrm{Vp}(\mathrm{m} / \mathrm{s})$ & $\begin{array}{c}\sigma_{\mathrm{f}} \\
(\mathrm{MPa})\end{array}$ & $\begin{array}{c}\sigma_{\mathrm{c}} \\
(\mathrm{MPa})\end{array}$ \\
\hline $\begin{array}{l}\text { ENTECSA } \\
\text { (13) }\end{array}$ & $\begin{array}{l}\text { Alabaster from Jiloca, } \\
\text { Aragon }\end{array}$ & 2.31 & - & 0.11 & - & - & - & 7.10 & 24.3 \\
\hline \multirow[t]{2}{*}{$\begin{array}{l}\text { Alfonso } \\
\text { et al. (14) }\end{array}$} & $\begin{array}{l}\text { Champagne and } \\
\text { Tobacco types }\end{array}$ & - & - & - & - & - & - & $5.3-5.7$ & 35.6 \\
\hline & Bardillo type & & & & & & - & 3.9 & 24.6 \\
\hline \multirow[t]{4}{*}{ This study } & Base (original) & 2.20 & 2.58 & 1.17 & (1) & (1) & (1) & (1) & (1) \\
\hline & Bottom shaft (original) & 1.77 & 6.45 & 3.64 & & & & & \\
\hline & Upper shaft (original) & 1.91 & 13.75 & 7.19 & & & & & \\
\hline & $\begin{array}{l}\text { Aragonese Bardillo } \\
\text { type (restored bases) }\end{array}$ & 227 & $0.67-0.72$ & $<1$ & $146 \pm 5$ & $22.20 \pm 0.5$ & $\begin{array}{l}3128(\mathrm{x}) \\
3128(\mathrm{y}) \\
3155(\mathrm{z})\end{array}$ & - & $26.6 \pm 1$ \\
\hline
\end{tabular}

(1) Very small samples to test. 
20 cycles, up to cover approximately $80 \%$ to $90 \%$ of the sample surface. After measuring the color in dry conditions, the samples were dampened with a sponge to recreate the initial measuring conditions. The wet slabs showed a lighter color than initial slabs but due to the new white lines around the preexistent fissures, more evident after 20 cycles. After

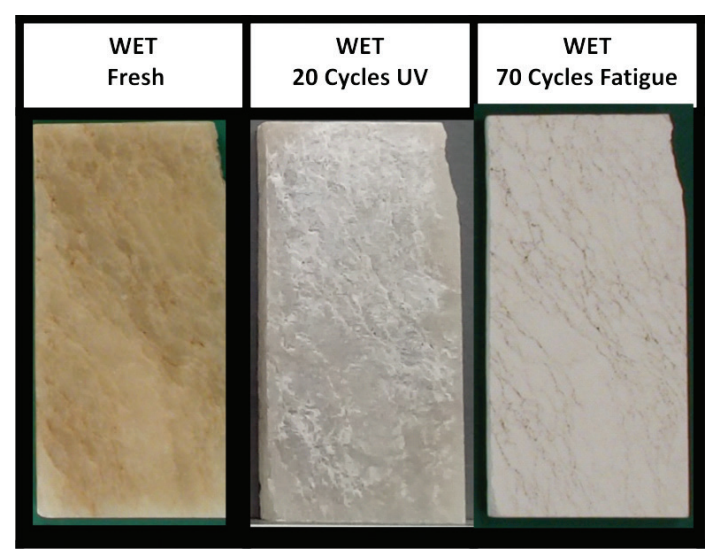

FIgURE 3. Surface appearance after thermal fatigue test. the second test, carried out afterwards on the same samples, the slabs become completely white with almost no differences between the dry and the wet conditions. The small differences were located on the fissures, with light brown color which turned in darker colors after wetting. The aspect of the samples is shown in Figure 3.

The color evolution from the fresh stone slightly dampened to the dry samples with the white powdery layer was very evident during the first cycles and only small variations were measured from then. Initial values of lightness $\left(\mathrm{L}^{*}\right)$ were medium/dark due to the sample's translucency and changed to values around 90 with the bassanite transformation. The decrease in $b^{*}$ from yellow colors to white ones was also remarkable (Figure 4).

The color evolution between wet samples showed the same trend but with bigger differences from 20 cycles to the end of the following 70 cycles. The tone of the final samples ( $a^{*}$ and $b^{*}$ parameters) was more vivid in the wet samples due to brownishing of the fissures filling in contact with water.

DRX analyses confirmed the bassanite presence, with around $65 \%$ for the slabs and $40 \%$ for the cubes, which indicated that the transformation

\section{Dry conditions}

$\mathbf{L}^{*}$

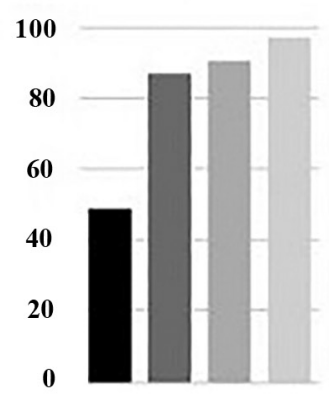

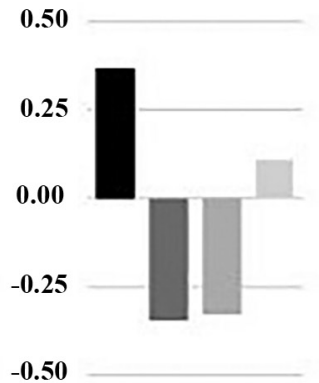

$b^{*}$

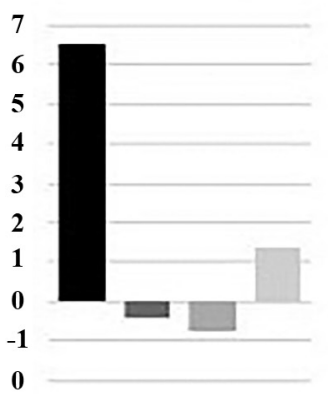

Fresh

a 10 cycles $105^{\circ} \mathrm{C}$

$\because 20$ cycles $105^{\circ} \mathrm{C}$

III 70 cycles $90^{\circ} \mathrm{C}$

\section{Wet conditions}

$\mathbf{L}^{*}$

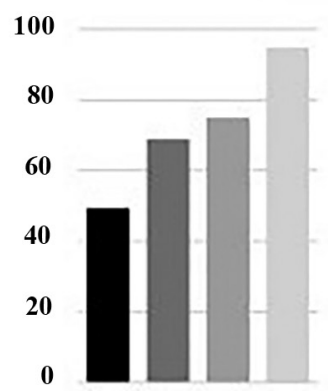

$a^{*}$

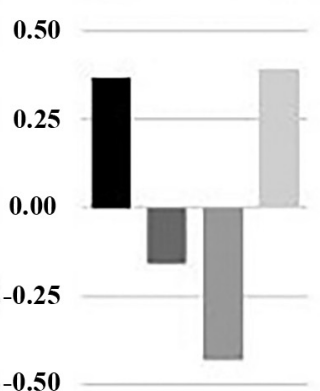

b*

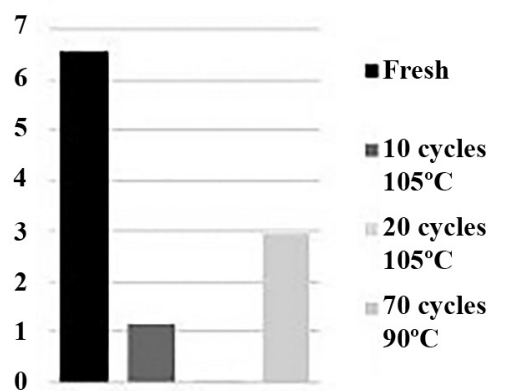

FIGURE 4. Color evolution after thermal tests in dry and wet measurement conditions. 
was not complete. Microscopical observations of the sound stone before testing and the slabs and the cubes after thermal tests, revealed notable differences between them (Figure 5). The heated samples exhibited a change in the texture, with a decomposition in micrograins that corresponded to fibrous bassanite (center and right, also observed in (15)). With non-polarized light, the bassanite advance from the fissures is clear. Crystals are homogeneous in size, with dimensions between 150-200 $\mu \mathrm{m}$. Anhydrite proportion increased from around 5\% in the cubes and $10 \%$ on the slabs, close to DRX results.

The slabs did not show any measurable bowing deformation. The stone texture adapted to temperature changes without any difference through the sample. Capillary water uptake was measured after 20 and the following 70 cycles of thermal variations. The initial capillary coefficient was null and so was after 20 cycles. The fissure network had not suffered any variation that would allow the water entering through the stone. At the end of all the tests, the average capillary coefficient increased to $146+-5 \mathrm{~g} / \mathrm{m}^{2} \mathrm{~s}^{1 / 2}$. The porosity calculated by the hydrostatic measure method (EN 1936) revealed a porosity at the end of the test of $24-28 \%$, very different from the $<1 \%$ of the fresh samples. Mercury porosimetry revealed an increase of porosity up to $8 \%$ with a unimodal distribution and a peak around $0.15 \mu \mathrm{m}$ (Figure 6).

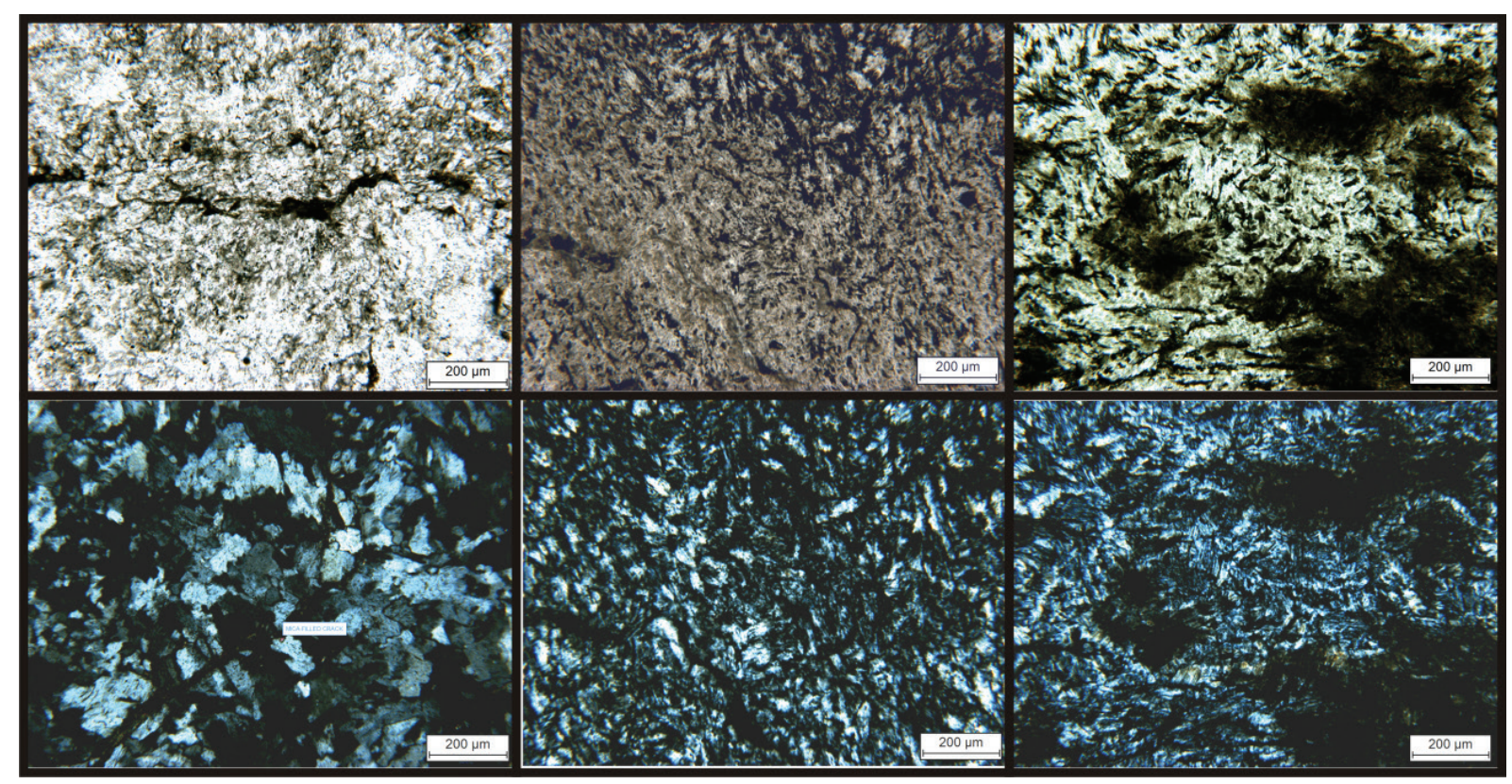

FiguRE 5. Microscopical observation with non-polarized (up) and polarized (bottom) light. Sound alabaster with alabastrine texture (left); cubes after insolation test and the textural transformation to bassanite (center); slabs after insolation test showing the progression of the textural transformation (right).
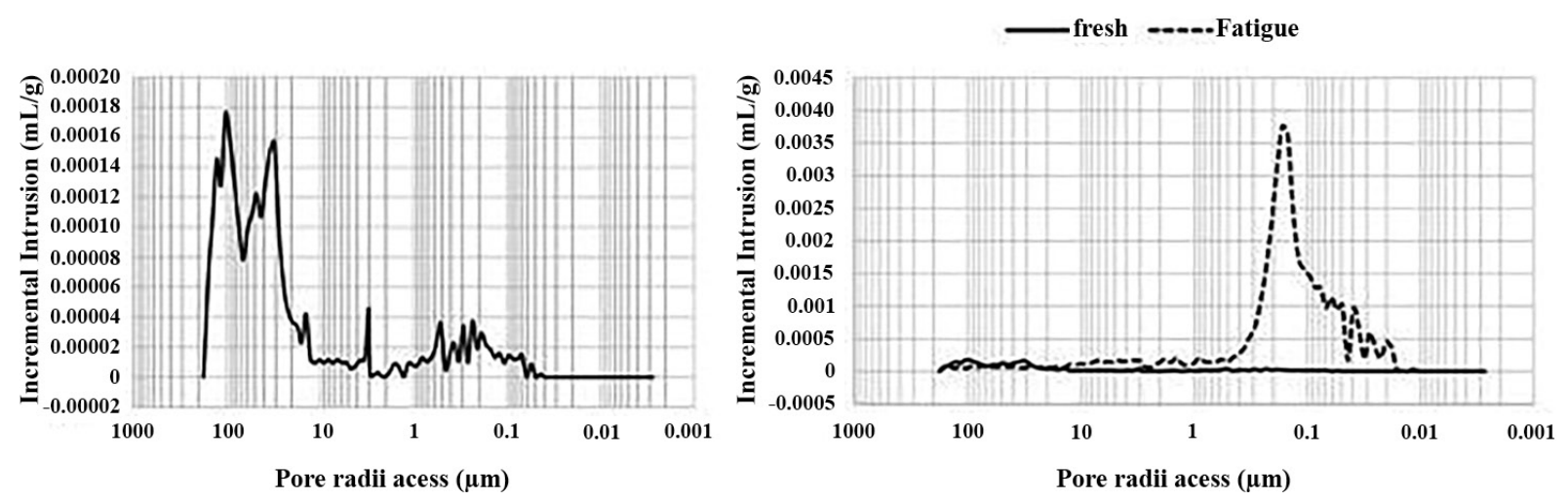

FIGURE 6. Pore radii access distribution obtained by $\mathrm{Hg}$ porosimetry of the fresh samples (left) and compared after thermal fatigue (right, vertical axis $\mathrm{x} 20$ ). 


\subsubsection{Acid rain}

The visual differences denoted a great change between samples and between tests (passive and active immersion). For all the samples, the surface increased its roughness. For both tests, the samples with a white homogeneous texture dissolved uniformly while the samples showing fissures experimented a differential dissolution. The clays that filled the fissures dissolved or fell mechanically slower that the gypsum and that created, a relief on the surface.

After the passive immersion test, the cubes showed a shape of slightly truncated tetrahedra, keeping their dimension unaltered at the bottom and decreasing linearly through the top. That is due to the greater dissolution of the cube vertices completely exposed to the solution. During the active immersion the samples exhibited a homogeneous dissolution (Figure 7). The dimensions were measured in the fresh samples and after each week. The total volume loss for passive immersion was of $9 \%$ and for active immersion of $12.5 \%$, which highlighted the great dissolution of the samples in contact with water and the important effect of the run- off water.

The weight loss in all the samples followed a linear trend, with an $8 \%$ of weight loss in passive
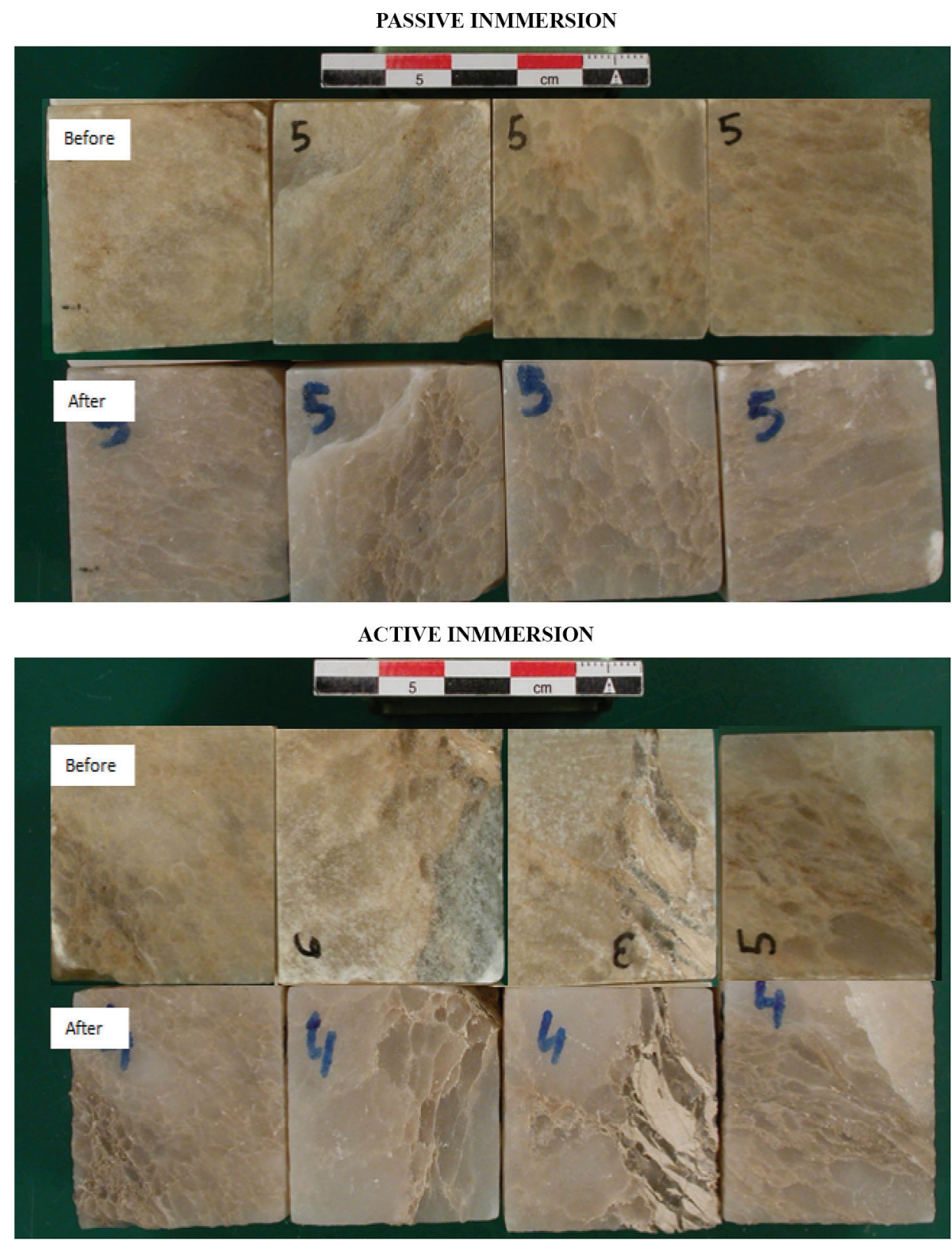

FIgURE 7. Comparison of surface condition after passive (up) and active (down) immersion tests. 
immersion samples and more than $13 \%$ in active immersion, values comparable to the volume loss (Figure 8). The minimum and maximum loss weight in the passive immersion were around $1.65 \mathrm{~g}$ and $2.0 \mathrm{~g}$ during the first 4 cycles and between $6.3 \mathrm{~g}$ and $7.3 \mathrm{~g}$ at the end of the test. In the active immersion, the deviation between samples was noticeable with a loss during the first 4 cycles between $0.4 \mathrm{~g}$ and 5.8 $\mathrm{g}$, and at the end of the 15 cycles between $9.5 \mathrm{~g}$ and $12.5 \mathrm{~g}$.

The dissolved cations of the solutions were analyzed every day. $\mathrm{Ca}^{2+}$ values corresponded to gypsum dissolution and $\mathrm{Mg}^{2+}$ to marly matrix components. The results showed that gypsum dissolves in a homogeneous way with similar values every day (Figure 9). Active immersion produced a greater dissolution due to the collision principle and the anomalous high peak was explained by the detachment of a piece of material, that increased that specific day the specific surface dissolving. The $\mathrm{Mg}^{2+}$ dissolved in water was extremely high the first day during active immersion and then stabilized. This high peak can be explained by the washing of all the detached clays on the surface due to the mechanical effect. In all the analyses carried out from the activepassive immersion, the $\mathrm{Mg}$ content was higher than in the passive one, indicating an action on the fracture fillings.

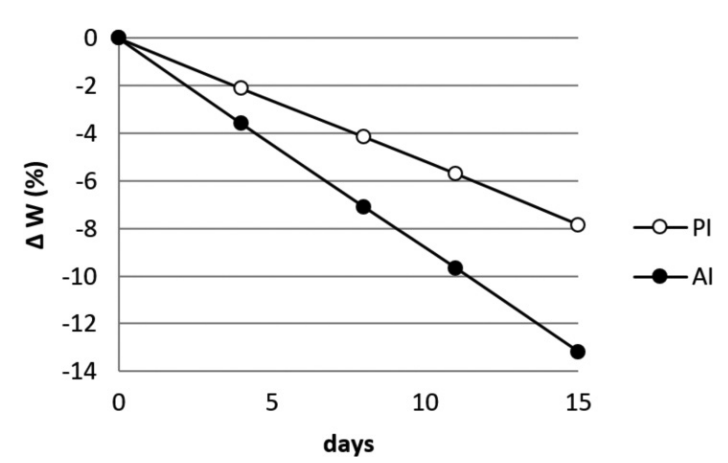

FIGURE 8. Weight loss in passive and active immersion tests.

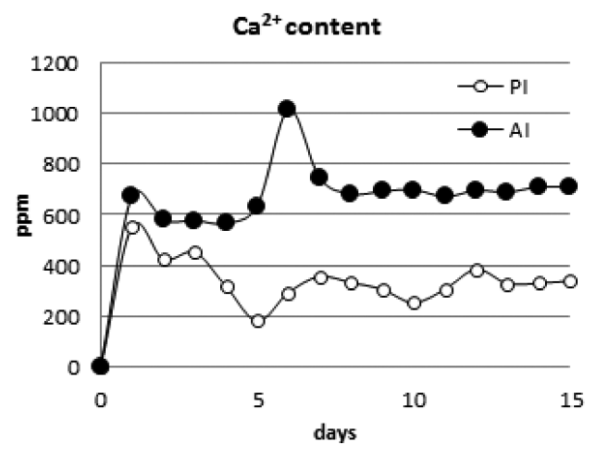

\subsubsection{Combined test}

After only 15 days some variations were observed in the prism, exposed to acid water on the basis and high temperature on one vertical face. Visual color change was observed in both exposed areas. The first centimeter from the bottom lost the powdery aspect due to the sawing process and obtained a wax gloss and darker colors. The face exposed to the heat showed a slight variation to white in some areas although not changing the stone general aspect. A dissolution and later precipitation in the water-air boundary was observed.

The weight loss measured every day revealed a sharp decrease during the first three days due possibly to the lack of $\mathrm{pH}$ equilibrium. After these days the loss was less accentuated but continuous with time (Figure 10). The measurement of the prism dimension highlighted the bottom dissolution with an area that decreased from $1623 \mathrm{~mm}^{2}$ to $1597 \mathrm{~mm}^{2}$, a height reduction from $69.96 \mathrm{~mm}$ to $69.21 \mathrm{~mm}$ and the univariate dimensions of the top surface.

\section{DISCUSSION}

Ageing tests revealed that alabaster was very susceptible to rain and insolation exposure. For the same intensity of the ageing test (360 hours of

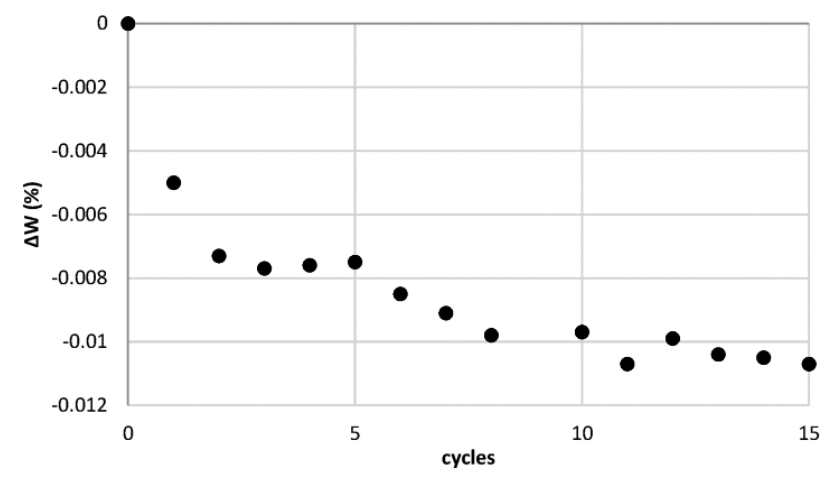

FIGURE 10. Weight loss during the combined test.

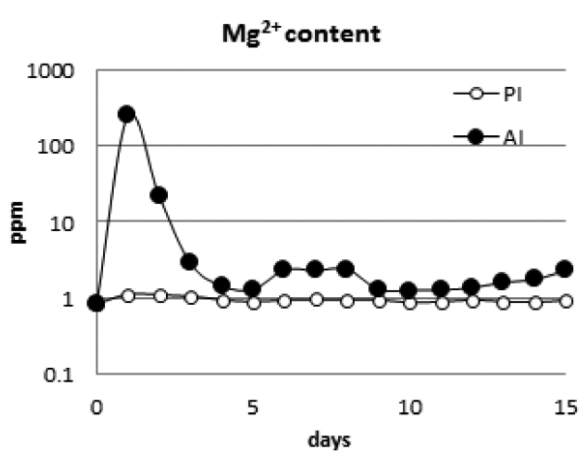

FIGURE 9. Evolution of the dissolved cations on the solution. 
thermal fatigue and 384 hours for immersion), rainwater that lead to stone dissolution produced more decay than the exposure to high temperatures. This fact was probed by the combined test.

Regarding rain events, two different processes occur when in contact with the outer column of Bishop's Palace of Tarazona. In the shaft, rainwater enters in contact with the stone and then the water run-off the column by gravity. Due to the low porosity of these stones, water does not enter but reacts with the surface while dropping. The ageing test that corresponded with this phenomenon was the active immersion. This test revealed that dissolution was more important that stationary immersion because salt dissolution involved two processes, i) the chemical reaction of the surface and ii) the fluid flow. When the rain water interacts with the stone, it has a $\mathrm{pH}$ around 5.6 due to the $\mathrm{CO} 2$ contained in the water. This acidity starts a reaction leading to dissolution during the run-off water along the stone surface. The solution $\mathrm{pH}$ increases slightly during the way down though it remains in acid values due to the short time needed to arrive to the column basis. The velocity and the intensity of the run-off water influence the reactions kinetics, with higher dissolution for higher velocities $(11,16)$. The column materials were the most homogeneous alabaster, which can be comparable with four of the samples used in the active immersion test. All kind of stones, homogeneous, andclay-rich, behaved similarly in this active immersion test with a recession of $10 \%$ after almost $400 \mathrm{~h}$ of water exposition.

Then, the rain water reached the basis of the column and stagnate there. Its $\mathrm{pH}$ is less acidic before the contact with the stone due to its saturation in gypsum (17). Besides, dissolution is only produced by surface reaction since no flow occurs, and consequently the kinetic reactions are slowed. This case was simulated by the passive immersion test. According to the mentioned above, the dissolution rate of the tests decreased from around $110 \mathrm{~g} / \mathrm{m}^{2} /$ day for the active immersion test to around $65 \mathrm{~g} / \mathrm{m}^{2} /$ day for the passive one. The stone found in the basis of the columns in Tarazona corresponded with the more heterogeneous facies, with calcite in its composition and fractures filled with clays. Four of the samples used in the immersion tests corresponded to this stone type. In both tests, gypsum dissolved preferentially while the clays created a relief over the white areas. ICP-MS analyses confirmed the $\mathrm{Mg}$ and $\mathrm{Na}$ presence while $\mathrm{Fe}$ was not found in the solution. That composition matched with illite (found also with XRD) and possibly montmorillonite that is a swelling clay. The dissolution of these four samples was slightly lower than for the homogeneous samples, since calcite has a slower dissolution kinetics in water and clays are more prone to disaggregate due to mechanical forces, i.e. flow, and remained stable in stationary environments.
Even with all the parameters for being less weathered than the shaft (stone more resistant to water, run-off water with higher $\mathrm{pH}$, stationary flow) the basis of the columns looked more weathered than the shaft. Due to the climatic conditions of Tarazona's area, with several rainy days even during the dry months, the cycles of wetting-drying seemed to produce more damage that dissolution by water stagnation. During the cycles, a flow is produced during the wetting (arrival of run-off water), and also a molecules movement during evaporation. This flow activates the dissolution reaction but also produces a mechanical effect on clays that are detached from the stone. This creates an increase on specific surface in which the new run-off water may act, enhancing the basis deterioration. In addition, dissolution is a linear process for natural stones, however, close to equilibrium the dissolution is inhibited (18). Due to climate, it seems probable that evaporation occurs before equilibrium.

Regarding the deformation due to the insolation exposure observed in other studies (4), crystalline stones may deform due to the temperature and humidity differences between the outer millimeters of the surface and the inner core of the stone. In addition, if the mineral is translucent, as is gypsum, the degree of light penetration can be substantial, and can produce the same stresses in deeper areas (19). Thermal fatigue tests did not produce any concave or convex deformation even if prior test with other kind of stones had positive results. Due to the translucency and the small thickness of the samples, the temperature gradient was negligible, and all the crystals dilated and contracted at the same time. In addition, textural features such as straight grain boundaries or heterogeneous grain size $(6,20,21)$ which favor bowing did not appeared in the studied samples.

The most important deterioration linked to temperature changes was the progressive dehydration, i. e. bassanite transformation, translated visually as color variation from light brown to white. To simulate the transformation rate, the stequiometric balance was calculated relating the molar masses and the sample weight as follows (22):

$$
\left[\alpha_{b}=\frac{M_{g}}{M_{g}-M_{a}} \frac{m_{0}-m_{t}}{m_{0}}\right]
$$

$\mathrm{Mg}$ and Ma are the molar mass of the minerals, $172.17 \mathrm{~g} / \mathrm{mol}$ for gypsum and $145.14 \mathrm{~g} / \mathrm{mol}$ for bassanite; $\mathrm{m} 0$ is the mass of the fresh samples and $\mathrm{mt}$ the mass after the complete test of thermal fatigue that is 90 cycles corresponding to 360 hours. The results gave a value of $\alpha \mathrm{b}$ of 0.88 with a deviation of 0.04 indicating that the transformation to bassanite was not completed and in agreement with XDR 
results. This transformation involved an increase in porosity by hydric methods from 0 to $28 \%$ but not in volume (in agreement to 15, 22, 23). Mercury porosimetry revealed only an increase from 0.5 to $8.6 \%$. That indicated that for this kind of transformations and samples, this technique was not the most suitable and a kind of porosity was not measured. Even if this study uses an accelerated ageing test with temperatures of up to $90^{\circ} \mathrm{C}$, bassanite transformation may start from $40^{\circ} \mathrm{C} \mathrm{(4),} \mathrm{that} \mathrm{is} \mathrm{a} \mathrm{temperature} \mathrm{easily}$ reached in Tarazona area. The basal part of the column showed a 3\% of bassanite, that indicated that the transformation was possible in that environmental conditions. The reason that basal stone showed bassanite and not the entire column with the same exposition is that bassanite transformation starts around fissures, filled with phyllosilicates of higher albedo. The basal stone was the most heterogeneous, and phyllosilicates-rich that favorizes the transformation around them. In general, the deterioration of the columns was related to the exposition and orientation of the insulation. Thus, protected parts were not affected equally because of the reached temperatures were lower than in the exposed ones.

\section{CONCLUSIONS}

Alabaster exposed to environment is strongly affected by dissolution from rainwater, by run-off water but also by stagnated water in plinths or copings. The loss of material is evident, but porosity does not change, keeping the structural properties of the inner core intact. The temperature variation produces a long-term decay that involves the dehydration to bassanite, which can start at $40^{\circ} \mathrm{C}$ and entails an increase in porosity. This change produces a higher dissolution and also structural weakness if the transformation reaches the inner core. The early stages of dehydration reveal an evident change in color that will allow to detect the transformation and to adopt prevention measures before an irreversible decay. The main solution to avoid the dissolution and the permanent solar exposure consists of the physical protection of alabaster building elements as well as drainage of water mainly on horizontal surfaces in contact with them. Other alternatives are treatments to avoid surface dissolution, use in areas of less sunshine and frequent maintenance measures.

\section{ACKNOWLEDGEMENTS}

The authors acknowledge the Universidad Politécnica de Madrid for the EEBB mobility fellowship and the Fundación Tarazona Monumental and architect José M. Valero. Also, to Alexandra Guillaneuf for the chemical analysis, Julien Hubert for the $\mathrm{Hg}$ porosimetry analysis, Xavier Drothiere for the photographic support and Enrique Areces and Nicanor Prendes for XRD collaboration.

\section{REFERENCES}

1. Cantos, O.; Criado, J. (2011) El alabastro, un mineral singular. Reflexiones sobre su uso en las artes plásticas y la construcción, De las Artes 7:257-268.

2. Schofield, P.F.; Knight K.S.; Stretton, I.C. (1996) Thermal expansion of gypsum investigated by neutron powder diffraction. American Mineralogist. 81 [7-8], 847-851. https:// doi.org/10.2138/am-1996-7-807

3. Cantos Martinez, O. (2011) El alabastro, un mineral singular. Reflexiones sobre su uso en las artes plásticas y la construcción. In Aguilera Aragón, I., y Ona González, J. L. (coords.), Delimitación comarcal de Zaragoza, Zaragoza, Gobierno de Aragón, 257-268. https://www.academia. edu/35596392/_El_alabastro_un_mineral_singular.

4. Gisbert, J.; Galarreta, S. (2015) El alabastro: patología en su uso arquitectónico y metodología específica para su estudio, ReCoPaR N $\mathrm{N}^{\circ} 11,8-17$.

5. Malaga, K.; Schouenborg, B.; Grelk, B. (2008) Bowing and expansion of natural stone panels: marble and limestone testing and assessment, Mater. Construcc. 58 [289-290], 97-112. https://doi.org/10.3989/mc.2008.v58.i289-290.84

6. Vázquez, P.; Siegesmund, S.; Alonso, F.J. (2011) Bowing of dimensional granitic stones. Environ. Earth Sci. 63 [7-8], 1603-1612. https://doi.org/10.1007/s12665-010-0882-y

7. Kloppmann, W.; Leroux, L.; Bromblet, P.; Guerrot, C.; Proust, E.; Cooper, A.H.; Worley, N.; Smeds, S.-A., Bengtsson, H. (2014) Tracing Medieval and Renaissance alabaster works of art back to quarries: a multi-isotope (Sr, S, O) Approach, Archaeometry 56 [2], 203-219 https:// doi.org/10.1111/arcm.12008

8. Criado, J. (1988) Maestre Guillaume Brimbeuf, ejemplo de las relaciones artísticas entre Aragón y Navarra a mediados del XVI. Príncipe de Viana ler Congreso General de Historia de Navarra. 6. Comunicaciones, Pamplona, 1988: 73-86.

9. Monjo, J.; Bustamante, R.; Rodríguez-Monteverde, P.; Herrero, M.T., Martínez, L.; Cardona, L. (diciembre 2014), Estudio de consolidación del Palacio Episcopal de Tarazona, Fundación Tarazona Monumental.

10. Grossi, C.M.; Alonso, F.J.; Esbert, R.M., Rojo, A. (2007) Effect of laser cleaning on granite color. Color Research \& Applic. 32 [2], 152-159. https://doi. org/10.1002/col.20299

11. Eyssautier-Chuine, S.; Marin, B.; Thomachot-Schneider, C.; Fronteau, G.; Schneider, A.; Gibeaux, S.; Vázquez, P. (2016) Simulation of acid rain weathering effect on natural and artificial carbonate stones, Environ. Earth Sci. 75, [748], 1-19. https://doi.org/10.1007/s12665-016-5555-z

12. Arbotante Estudios Previos de Restauración (2016) Estudio petrográfico de muestras de alabastro procedentes del Palacio Episcopal de Tarazona. Dpto. Ciencias de la Tierra de la Universidad de Zaragoza.

13. ENTECSA Laboratorio de Ensayos Técnicos S.A. (1999) Características físico-mecánicas, Alabastro del Jiloca, Zaragoza.

14. Alfonso, P.; Parcerisa, D.; Grané, M.; Novoa, G. (2012) El alabastro de Fuentes de Jiloca: Patrimonio geológico e histórico. Geotemas 12, 19-22, https://www.researchgate. net/publication/277587782

15. Milsch, H.; Priegnitz, M. (2012) Evolution of microstructure and elastic wave velocities in dehydrated gypsum samples. Geoph. Res. Lett. 39, 24. https://doi.org/ 10.1029/2012GL053674.

16. Raines, M.A.; Dewers, T. A. (1997) Mixed transport/ reaction control of gypsum dissolution kinetics in aqueous solutions and initiation of gypsum karst. Chemic. Geolo. 140 [1-2], 29-48. https://doi.org/10.1016/ S0009-2541(97)00018-1

17. Kuechler, R.; Noack, K.; Zorn, T. (2004) Investigation of gypsum dissolution under saturated and unsaturated water conditions. Ecolog. Modell. 176 [1-2], 1-14. https://doi. org/10.1016/j.ecolmodel.2003.10.025

18. Jeschke, A.A.; Vosbeck, K.; Dreybrodt, W. (2001) Surface controlled dissolution rates of gypsum in aqueous 
solutions exhibit nonlinear dissolution kinetics. Geochim. Cosmochim. Acta. 65 [1], 27-34. https://doi.org/10.1016/ S0016-7037(00)00510-X

19. Hall, K. (2011) Natural building stone composed of light-transmissive minerals: impacts on thermal gradients, weathering and microbial colonization. A preliminary study, tentative interpretations, and future directions. Environ. Earth Sci. 62 [2], 289-297. https://doi.org/10.1007/ s12665-010-0522-6

20. Koch, A.; Siegesmund, S. (2004) The combined effect of moisture and temperature on the anomalous expansion behaviour of marble. Environ. Geolo. 46 [3-4], 350-363. https://doi.org/10.1007/s00254-004-1037-9
21. Logan, J.M. (2004) Laboratory and case studies of thermal cycling and stored strain on the stability of selected marbles. Environ. Geolo. 46 [3-4], 456-467. https://doi.org/ 10.1007/s00254-004-1047-7

22. Milsch, H.; Priegnitz, M., Blöcher, G. (2011) Permeability of gypsum samples dehydrated in air. Geoph. Res. Lett. 38 [18]. https://doi.org/10.1029/2011GL048797

23. Fusseis, F.; Schrank C.E.; Liu, J.; Karrech, A.; LlanaFunez, S.; Xiao, X. (2012) Pore formation during dehydration of a polycrystalline gypsum sample observed and quantified in a time-series synchrotron X-ray microtomography experiment. Solid Earth 3 [1], 71-86. https:// doi.org/10.5194/se-3-71-2012 